\title{
Recruitment mechanisms of tropical eels Anguilla spp. and implications for the evolution of oceanic migration in the genus Anguilla
}

\author{
Takaomi Arai $^{1, *}$, Daniel Limbong ${ }^{2}$, Tsuguo Otake ${ }^{3}$, Katsumi Tsukamoto ${ }^{1}$ \\ ${ }^{1}$ Ocean Research Institute, The University of Tokyo, Minamidai, Nakano, Tokyo 164-8639, Japan \\ ${ }^{2}$ Faculty of Fisheries and Marine Science, Sam Ratulangi University, Manado 95115, Indonesia \\ ${ }^{3}$ Faculty of Bioresources, Mie University, Kamihama, Tsu 514-8507, Japan
}

\begin{abstract}
Otolith microstructure and microchemistry of the tropical eels Anguilla celebesensis Kaup, A. marmorata Quoy \& Gaimard and A. bicolor pacifica Schmidt were examined in glass eels collected at the mouth of the Poigar River, north Sulawesi Island, Indonesia, throughout 1997. Ages at metamorphosis and recruitment, respectively, were 84 to $95 \mathrm{~d}$ and 104 to $118 \mathrm{~d}$ in A. celebesensis, 114 to $158 \mathrm{~d}$ and 144 to $182 \mathrm{~d}$ in A. marmorata, and 129 to $171 \mathrm{~d}$ and 158 to $201 \mathrm{~d}$ in A. bicolor pacifica. No significant differences were found in mean ages among months within any one species, whereas significant differences were found among species. Hatching was estimated to occur throughout almost the entire year in A. celebesensis and A. marmorata compared with intermittently over about 6 mo in A. bicolor pacifica. Based on year-round recruitment of A. bicolor pacifica at the mouth of the Poigar River in an earlier study and age at recruitment being constant throughout the year, the spawning season of this species may also occur throughout the year. In all species examined, positive linear relationships were found between age at metamorphosis and age at recruitment, suggesting that early metamorphosing larvae were recruited to freshwater habitats at an early age. Year-round recruitment of tropical glass eels to the river mouth would necessarily follow year-round spawning and stable recruitment age. Such a recruitment mechanism differs from that of temperate eels, the latter having a limited spawning season followed by a limited period of recruitment.
\end{abstract}

KEY WORDS: Tropical Anguilla spp. · Glass eel · Otolith · Growth increments · Sr:Ca ratios · Metamorphosis $\cdot$ Larval dispersal $\cdot$ Oceanic migration

Resale or republication not permitted without written consent of the publisher

\section{INTRODUCTION}

The freshwater eels of the genus Anguilla, being catadromous, migrate between freshwater growth habitats and offshore spawning areas. Among their various life-history events, metamorphosis from leptocephalus to glass eel is one of the most interesting phenomena. The timing of metamorphosis and the duration of the leptocephalus stage seem to constitute an

*Present address: Otsuchi Marine Research Center, Ocean Research Institute, The University of Tokyo, 2-106-1, Akahama, Otsuchi, Iwate 028-1102, Japan.

E-mail: arai@wakame.ori.u-tokyo.ac.jp important biological key for determining the geographical distribution of eels (Tsukamoto \& Umezawa 1994). Long-term larval migration in the sea might have been involved in the world-wide distribution of the genus and consequent speciation of Anguilla species (Tsukamoto 1994, Tsukamoto \& Aoyama 1998). Fifteen species of Anguilla have been reported worldwide, 10 being known from tropical regions (Ege 1939). Of the latter, 7 species/subspecies occur in the western Pacific around Indonesia: A. celebesensis, A. interioris, A. nebulosa nebulosa, A. marmorata, A. borneensis, A. bicolor bicolor and A. bicolor pacifica (Ege 1939, Castle \& Williamson 1974, Arai et al. 1999a). Recent mitochondrial DNA analysis has revealed that $A$. 
borneensis from Borneo Island is closest to the ancestral form among the 15 presently known species (Aoyama 1998). Furthermore, the tropical species seem to be more closely related to the ancestral form than their temperate counterparts. Aoyama suggested that freshwater eels originated in the present-day Indonesian region during the Cretaceous. Thus, studying larval migration and metamorphosis in tropical eels may provide some clues to understanding the nature of primitive forms of catadromous migration in freshwater eels and how the large-scale migration of temperate species became established.

Examination of otolith microstructure and microchemistry has revealed considerable information on the early life history of temperate Anguilla species including A. japonica, A. anguilla, A. rostrata, A. australis and $A$. dieffenbachi, there being many reports on the age and growth of their leptocephali (Castonguay 1987, Tabeta et al. 1987, Tsukamoto 1990, Tsukamoto \& Umezawa 1990, Tzeng 1990, Umezawa \& Tsukamoto 1990, Lecomte-Finiger 1992, Tzeng \& Tsai 1992, Cheng \& Tzeng 1996, Wang \& Tzeng 1998, Arai et al. 1999d, 2000b, Wang \& Tzeng 2000, Marui et al. 2001). We have determined that a marked increase in otolith increment width coincident with a drop in Sr:Ca ratios indicates the onset of metamorphosis, the latter apparently being completed before the maximum peak of otolith increment width (Otake et al. 1994, Arai et al. 1997). However, such information has been obtained mainly from temperate species, little being known about the early life history of tropical species, including aspects such as spawning area and season, larval growth and metamorphosis, migration and even recruitment of glass eels to estuarine habitats. One of the reasons for such oversights has its basis in the difficulty of identifying sympatric species with overlapping morphological characters (Tabeta et al. 1976a). For this

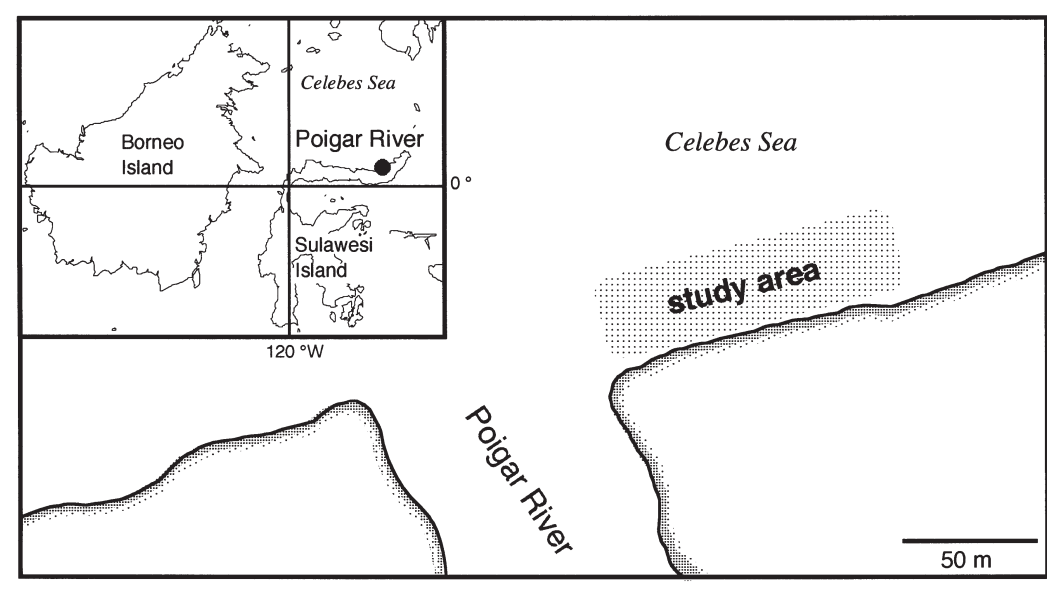

Fig. 1. Map showing mouth of the Poigar River and study area from which glass eels Anguilla spp. were collected reason, even species composition is poorly known in some tropical areas.

In the present study, we examined otolith microstructure and microchemistry of the tropical species Anguilla celebesensis Kaup, A. marmorata Quoy \& Gaimard and A. bicolor pacifica Schmidt, collected at the mouth of the Poigar River, north Sulawesi Island, throughout 1997, and determined the timing and duration of metamorphosis, inshore migration period, age at recruitment and hatching date. The results provided a basis for discussion on the larval migration mechanisms in these species. We also used data from this and previous studies on anguillid early life history in an attempt to understand the oceanic migration, evolution and distribution of Anguilla species.

\section{MATERIALS AND METHODS}

Fish. Anguilla celebesensis, A. marmorata and A. bicolor pacifica glass eels were collected at night (20:00 to 04:00 h) with triangular scoop nets (mouth $0.3 \mathrm{~m}^{2}$, mesh $1 \mathrm{~mm}$ ) at the mouth of the Poigar River, north Sulawesi Island, Indonesia (Fig. 1), at the new moon of each month of 1997. The glass eels sampled were preserved in $99 \%$ ethanol immediately after collection until species identification using mitochondrial DNA (mtDNA) genotypes (Arai et al. 1999a). Total length (TL) and predorsal, ano-dorsal and preanal lengths of the specimens were measured to the nearest $0.1 \mathrm{~mm}$, and the pigmentation stage was determined after Bertin (1956).

In months where only a few specimens were collected (February, March, September and December), all were examined (2 to 10 specimens), whereas in each of the other months (January, April to August, October and November), 30 specimens were randomly selected. Otolith analyses were performed on a total of 272 glass eels (189 specimens of Anguilla celebesensis, 68 specimens of $A$. marmorata and 15 specimens of $A$. bicolor pacifica: see Table 1).

Otolith preparation. Sagittal otoliths were extracted from each fish, embedded in epoxy resin (Struers, Epofix) and mounted on glass slides. After the radius was measured, otoliths were ground to expose the core using a grinding machine equipped with a diamond cup-wheel (Struers, DiscoplanTS), and further polished with 6 and $1 \mu \mathrm{m}$ diamond paste on an automated polishing wheel (Struers, Planopol-V). They were then cleaned in an ultrasonic 
bath and rinsed with deionized water for the following microchemical and microstructual examinations.

Otolith X-ray microprobe analysis. For electron microprobe analyses, 112 otoliths (10 specimens each month, except only 2 in September) were carboncoated by high-vacuum evaporator. Sr and Ca concentrations were measured along the longest axis of the otolith using a wavelength dispersive X-ray electron microprobe (JEOL JXA-733). Calcite $\left(\mathrm{CaCO}_{3}\right)$ and strontianite $\left(\mathrm{SrCO}_{3}\right)$ were used as standards. Accelerating voltage and beam current were $15 \mathrm{kV}$ and $7 \mathrm{nA}$, respectively. The electron beam was focused on a point about $1 \mu \mathrm{m}$ in diameter, with measurements taken at $1 \mu \mathrm{m}$ intervals. Each datum point represents the average of 3 measurements of $4.0 \mathrm{~s}$ each. Microprobe measurement points were taken along a burn transect from the otolith core to the outer margin. The average of successive data of $\mathrm{Sr}$ and $\mathrm{Ca}$ concentrations were pooled for every 10 successive growth increments and used for the life-history transect analysis.

Otolith increment analysis. Following the electron microprobe analysis, the otoliths were repolished (to remove the coating), etched with $0.05 \mathrm{M} \mathrm{HCl}$, and vacuum-coated with Pt-Pd in an ion-sputterer for scanning electron microscope (SEM, Hitachi S-4500) observations. Otoliths of a further 160 specimens were also ground, the resulting surfaces being etched and coated by the same procedure as for the SEM observations. SEM photographs taken at various magnifications $(150 \times, 180 \times, 1000 \times, 1500 \times)$ were used to count the number of growth increments and measuring their width. The average of every 10 successive rings between the hatch check and the edge were used to analyze otolith growth. According to the findings of Tsukamoto (1989), Umezawa et al. (1989), Umezawa \& Tsukamoto (1991), Martin (1995) and Arai et al. (2000a), the growth rings in Anguilla japonica, A. rostrata and $A$. celebesensis are formed daily; therefore the equivalent rings in $A$. marmorata and $A$. bicolor pacifica were also considered to be formed daily.

Early life history analysis. Based on previous data for otolith increment width and Sr:Ca ratios in Anguilla japonica (Otake et al. 1994, Arai et al. 1997), A. rostrata (Wang \& Tzeng 1998, Arai et al. 2000b), A. australis (Arai et al. 1999d), A. bicolor pacifica (Arai et al. 1999c), A. celebesensis, A. marmorata and A. bicolor bicolor (Arai et al. 1999d), A. anguilla (Arai et al. 2000b) and A. dieffenbachi (Marui et al. 2001), age at Point $M$ (Fig. 2) (i.e. the point at which a marked increase in otolith increment width coincides with a drop in $\mathrm{Sr}: \mathrm{Ca}$ ratios) was regarded as the onset of metamorphosis in each species examined herein. Duration of the metamorphosis stage was regarded as the period between the onset of a marked increase in otolith increment width and the time at which maximum width was

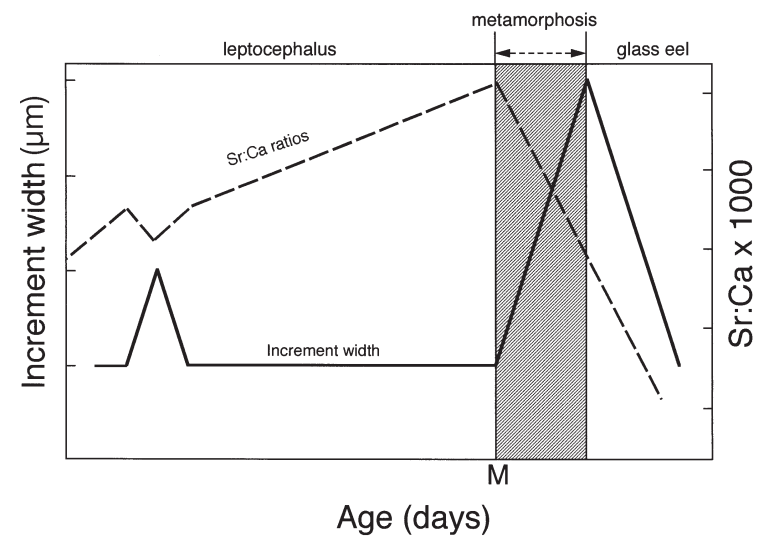

Fig. 2. Anguilla spp. Conceptual model showing changes in otolith incremental widths and $\mathrm{Sr}$ :Ca ratios during the early life history. M: timing of metamorphosis

recorded. The increments outside the maximum recorded otolith increment width were interpreted as representing the inshore migration period. The number of increments between the hatch check and otolith edge (Fig. 3) was regarded as the age at recruitment.

Statistical analyses. Differences among data were tested by an analysis of variance (ANOVA) and subsequently by Scheffé's multiple range test for the combination of 2 data sets. Significance of the correlation coefficient and regression slope were tested by Fisher's Z-transformation (Sokal \& Rohlf 1969).

\section{RESULTS}

\section{Size and stage at recruitment}

Anguilla celebesensis was the dominant anguillid species in the sampling area, constituting $69.5 \%$ of the total glass eel catch in 1997 . It was also seen throughout most of the year. A. marmorata (25\%) was also seen throughout the year, whereas $A$. bicolor pacifica $(5.5 \%)$ occurred only in January, March, April, October and December (Table 1).

The total lengths (mean \pm SD) of the glass eels of Anguilla celebesensis, A. marmorata and A. bicolor pacifica collected throughout 1997 were $44.7 \pm 2.5 \mathrm{~mm}$ (January) to $52.6 \pm 1.8 \mathrm{~mm}$ (June), $47.9 \pm 2.5 \mathrm{~mm}$ (February) to $52.3 \pm 1.0 \mathrm{~mm}$ (June) and $48.6 \mathrm{~mm}$ (April) to $51.5 \mathrm{~mm}$ (November), respectively (Table 1).

Pigmentation in all the glass eels was poorly developed, being limited to the caudal or skull, caudal and rostral regions of the body; the samples were thus classified as being at the glass eel stage (VA or VB). The level of pigmentation suggested that the specimens had only recently arrived at the river mouth. 
Table 1. Anguilla spp. Tropical glass eels collected at mouth of the Poigar River in 1997, with number (n) and total lengths (TL in $\mathrm{mm}$, mean $\pm \mathrm{SD}$ ) of specimens examined in the study. ns: no sample

\begin{tabular}{|c|c|c|c|c|c|c|c|}
\hline \multirow[t]{2}{*}{ Sampling date } & \multirow{2}{*}{$\begin{array}{l}\text { Total no. } \\
\text { examined }\end{array}$} & \multicolumn{2}{|c|}{ A. celebesensis } & \multicolumn{2}{|c|}{ A. marmorata } & \multicolumn{2}{|c|}{ A. bicolor pacifica } \\
\hline & & $\mathrm{n}$ & TL (mm) & $\mathrm{n}$ & TL (mm) & $\mathrm{n}$ & TL (mm) \\
\hline $10 \mathrm{Jan}$ & 30 & 15 & $44.7 \pm 2.5$ & 11 & $48.0 \pm 1.8$ & 4 & $48.7 \pm 1.1$ \\
\hline 9 Feb & 10 & 5 & $45.6 \pm 0.7$ & 5 & $47.9 \pm 2.5$ & & $\mathrm{~ns}$ \\
\hline $10 \mathrm{Mar}$ & 10 & & ns & 7 & $48.4 \pm 1.3$ & 3 & $49.0 \pm 1.1$ \\
\hline 9 Apr & 30 & 24 & $45.9 \pm 1.6$ & 4 & $48.8 \pm 3.0$ & 2 & 48.6 \\
\hline 8 May & 30 & 29 & $48.1 \pm 1.9$ & 1 & 50 & & ns \\
\hline 7 Jun & 30 & 26 & $52.6 \pm 1.8$ & 4 & $52.3 \pm 1.0$ & & ns \\
\hline $7 \mathrm{Jul}$ & 30 & 4 & $47.8 \pm 3.1$ & 26 & $51.3 \pm 1.4$ & & ns \\
\hline 5 Aug & 30 & 29 & $49.3 \pm 1.5$ & 1 & 52.3 & & ns \\
\hline $3 \mathrm{Sep}$ & 2 & & ns & 2 & 50.5 & & ns \\
\hline 31 Oct & 30 & 23 & $47.9 \pm 1.6$ & 3 & $52.2 \pm 3.1$ & 4 & $49.3 \pm 2.4$ \\
\hline $29 \mathrm{Nov}$ & 30 & 27 & $46.3 \pm 1.5$ & 3 & $51.4 \pm 0.8$ & & 51.5 \\
\hline $30 \mathrm{Dec}$ & 10 & 7 & $45.6 \pm 1.7$ & 1 & 51.9 & 2 & $48.7 \pm 1.1$ \\
\hline
\end{tabular}

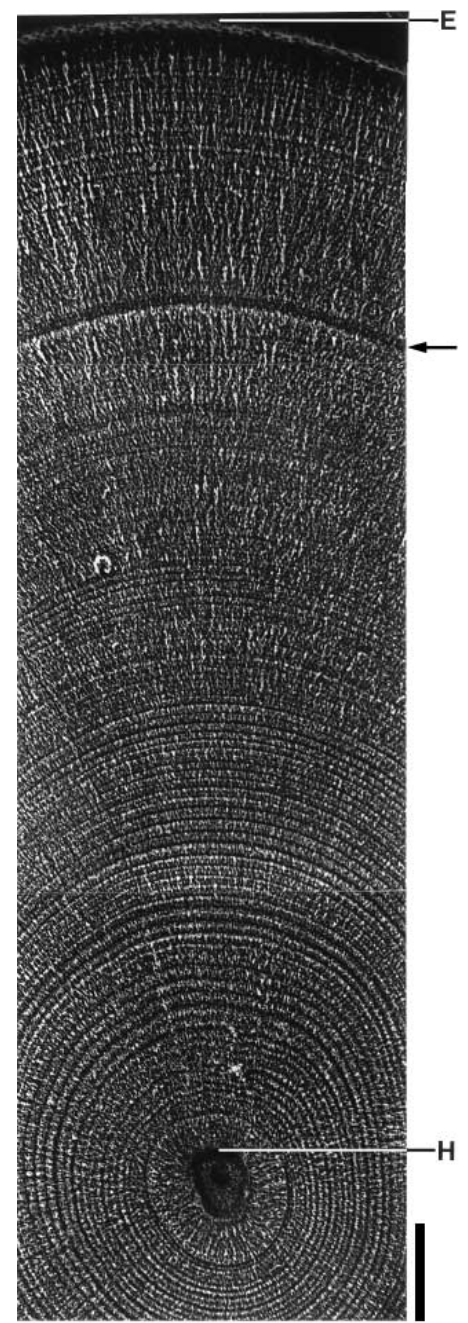

Fig. 3. Anguilla celebesensis. SEM photograph showing otolith growth increments of a glass eel $(\mathrm{TL}=49.1 \mathrm{~mm})$ collected at the mouth of Poigar River on 7 June 1997. Arrow indicates check at the onset of rapid increase in increment width, H: hatch check, E: otolith edge (Scale bar $=10 \mu \mathrm{m})$

\section{Otolith microstructure}

The otolith core was a deep hole in the center of the etched otolith surface, a hatch check being visible as a deep circular groove surrounding the hole (Fig. 3). Distinct concentric growth increments were observed in all otoliths examined. These concentric rings were similar in configuration to those previously reported in Anguilla japonica (Tabeta et al. 1987, Tsukamoto 1990, Tzeng 1990, Umezawa \& Tsukamoto 1990, Tzeng \& Tsai 1992), A. anguilla (Lecomte-Finiger 1992, Arai et al. 2000b), A. rostrata (Wang \& Tzeng 1998, Arai et al. 2000b), A. australis (Arai et al. 1999d), A. bicolor pacifica (Arai et al. 1999c), A. celebesensis, A. marmorata and $A$. bicolor bicolor (Arai et al. 1999b) and $A$. dieffenbachi (Marui et al. 2001). Although a metamorphosis check (Fig. 3) was observed consistent with the onset of metamorphosis in A. anguilla (LecomteFiniger 1992) and A. japonica (Cheng \& Tzeng 1996), this check was apparent in only 43 of the 272 specimens examined $(16 \%)$.

\section{Otolith growth pattern}

Patterns of change in otolith increment widths from the core to the edge relative to the life-history transects of each species are shown in Fig. 4. The common pattern observed in all specimens examined comprised 4 stages with drastic changes occurring in the last two, similar to the patterns previously reported for Anguilla japonica (Otake et al. 1994, Cheng \& Tzeng 1996, Arai et al. 1997), A. rostrata (Wang \& Tzeng 1998, Arai et al. 2000b), A. australis (Arai et al. 1999d), A. bicolor pacifica (Arai et al. 1999c), A. celebesensis, A. marmorata and A. bicolor bicolor (Arai et al. 1999b), A. anguilla (Arai et al. 2000a) and $A$. dieffenbachi (Marui et al. 2001). Otolith incre- 


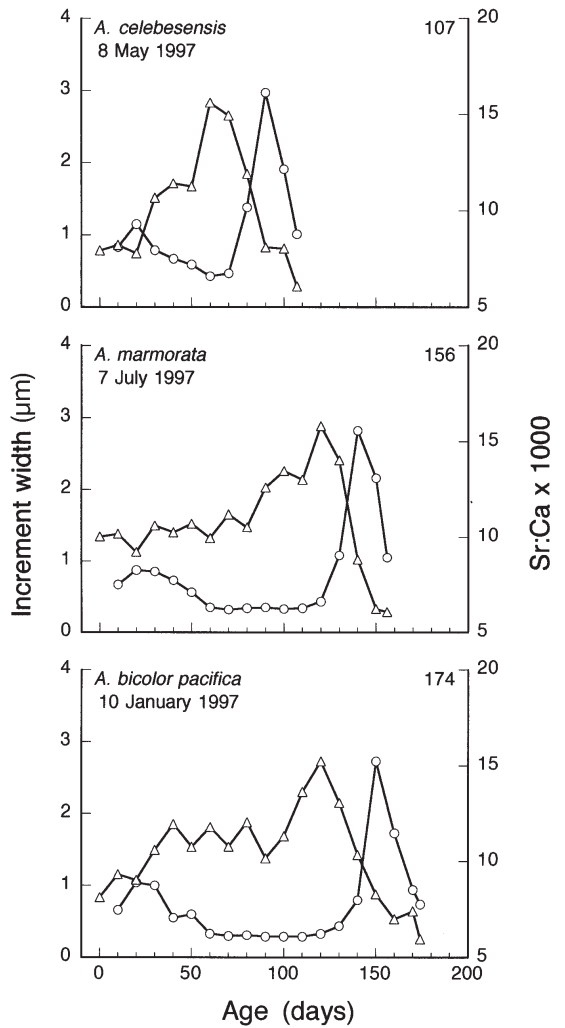

Fig. 4. Anguilla spp. Profiles of otolith increment widths from the core to the edge $(\mathrm{O})$ and otolith $\mathrm{Sr}$ :Ca concentration ratios measured with a wavelength dispersive electron microprobe from the core to the edge $(\Delta)$. Each data point represents averaged data for $10 \mathrm{~d}$; numbers on upper right: age (d). Specimens were collected at the mouth of the Poigar River in 1997

ment widths increased between the hatch check and Age 20 to $40 \mathrm{~d}$ in each species (first stage), thereafter becoming constant or gradually decreasing (average widths 0.41 to $0.47 \mu \mathrm{m}$ ) (second stage). Beyond Age $88 \pm$ $9.8 \mathrm{~d}($ mean $\pm \mathrm{SD}$ ) in Anguilla celebesensis, $128 \pm 15.2 \mathrm{~d}$ in A. marmorata and $141 \pm 20.9 \mathrm{~d}$ in A. bicolor pacifica, increment widths increased sharply to a maximum (average 2.81 to $3.02 \mu \mathrm{m}$ ) (third stage), followed by a rapid drop (fourth stage).

\section{Otolith Sr:Ca ratios}

Otolith $\mathrm{Sr}$ :Ca ratios changed dramatically along the life-history transect in all species (Fig. 4), a common pattern of microchemical changes being observed in all the glass eels examined. Sr:Ca ratios, averaging 8.3 to $9.6 \times 10^{-3}$ at the core, dropped slightly over what approximated the first stage of otolith growth, subsequently increased to a maximum level (average 15.7 to $17.2 \times 10^{-3}$ ) in the second stage, and markedly decreased thereafter toward the edge. The last stage of changing Sr:Ca ratios coincided with the onset of the third stage of otolith growth. The minimum average Sr:Ca values (6.3 to $7.2 \times 10^{-3}$ ) were recorded in the outermost region of the otolith in each species.

\section{Age at and duration of metamorphosis}

The mean ages at metamorphosis of Anguilla celebesensis, A. marmorata and A. bicolor pacifica in each month ranged from 84 (October) to $95 \mathrm{~d}$ (February), 114 (June) to $158 \mathrm{~d}$ (August) and 129 (January) to $171 \mathrm{~d}$ (December), respectively (Fig. 5). No significant difference occurred among months in any one species (ANOVA, $p>0.1$ ), although significant differences occurred in all combinations among species (ANOVA, $\mathrm{p}<0.001$ to 0.0001). Ages at metamorphosis of A. celebesensis, A. marmorata and $A$. bicolor pacifica were (mean $\pm \mathrm{SD}$ ) $88 \pm 9.8,128 \pm 15.2$ and $141 \pm 20.9 \mathrm{~d}$, respectively.

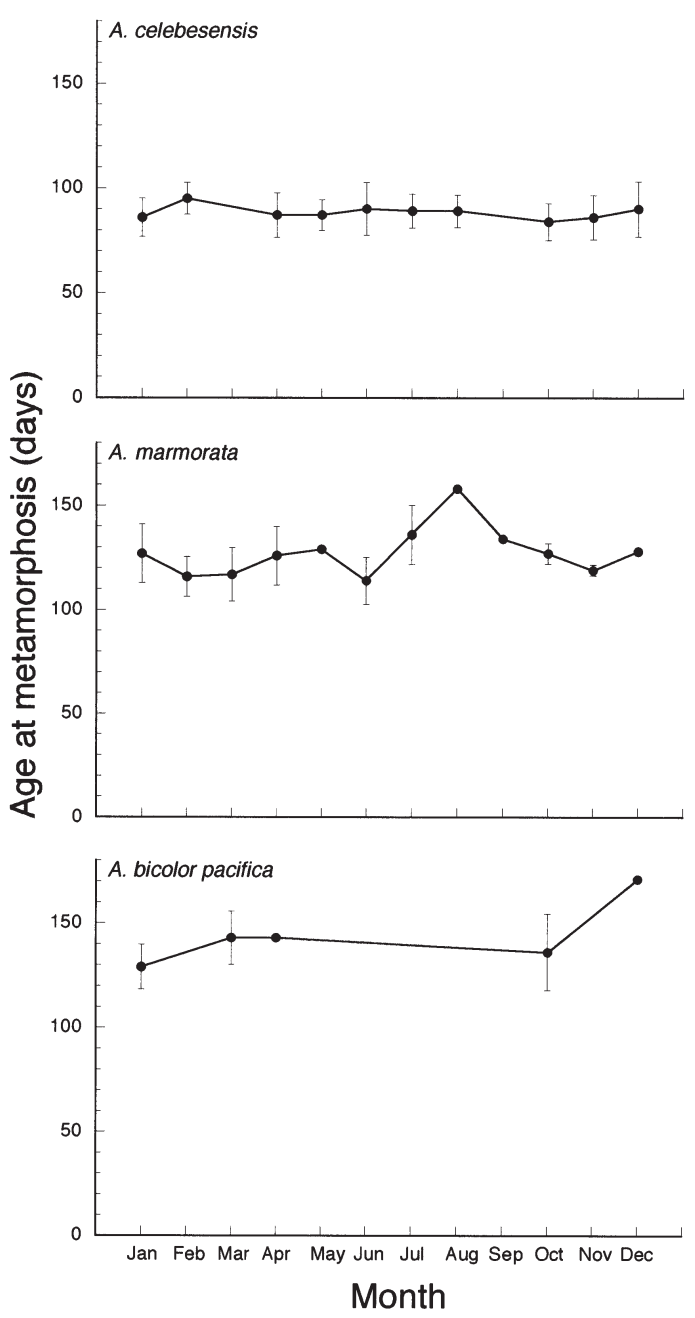

Fig. 5. Anguilla celebesensis, A. marmorata and A. bicolor pacifica. Seasonal variations in age at metamorphosis of glass eels caught at the mouth of the Poigar River in 1997 
The mean durations of the metamorphosing stage of Anguilla celebesensis, A. marmorata and A. bicolor pacifica in each month ranged from 15 (January, April) to $18 \mathrm{~d}$ (February, July), 15 (September) to $27 \mathrm{~d}$ (December) and 14 (October) to $25 \mathrm{~d}$ (April), respectively (Fig. 6). No significant difference occurred among months in any one species (ANOVA, $\mathrm{p}>0.1$ ). Although a significant difference was found between $A$. celebesensis and $A$. marmorata (ANOVA, $\mathrm{p}<0.0001$ ), no others were apparent for other combinations (ANOVA, $p>0.1$ ). The duration of the metamorphosis stages of $A$. celebesensis, A. marmorata and $A$. bicolor pacifica were (mean $\pm \mathrm{SD}$ ) $16 \pm 3.5,19 \pm 4.2$ and $18 \pm 5.8 \mathrm{~d}$, respectively.

\section{Age at recruitment}

The mean ages at recruitment of Anguilla celebesensis, A. marmorata and A. bicolor pacifica in each

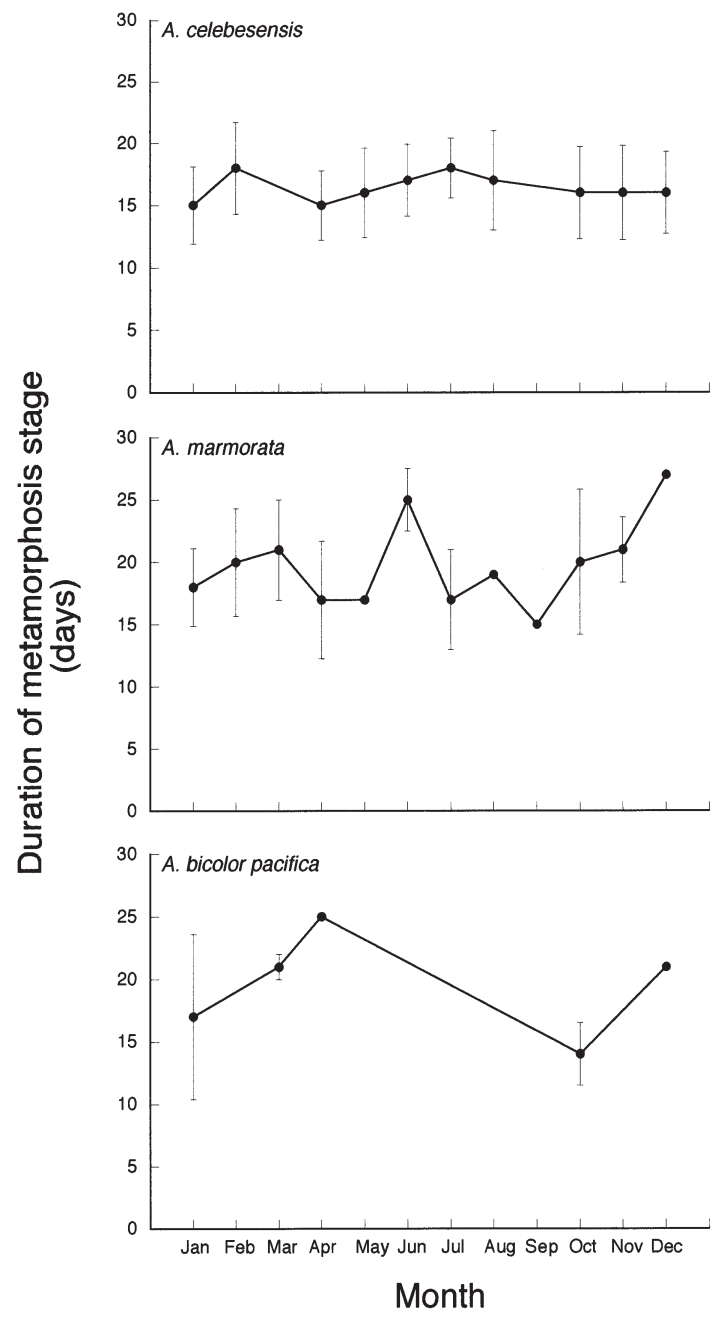

Fig. 6. Anguilla celebesensis, A. marmorata and A. bicolor pacifica. Seasonal variations in duration of metamorphosis of glass eels caught at the mouth of the Poigar River in 1997

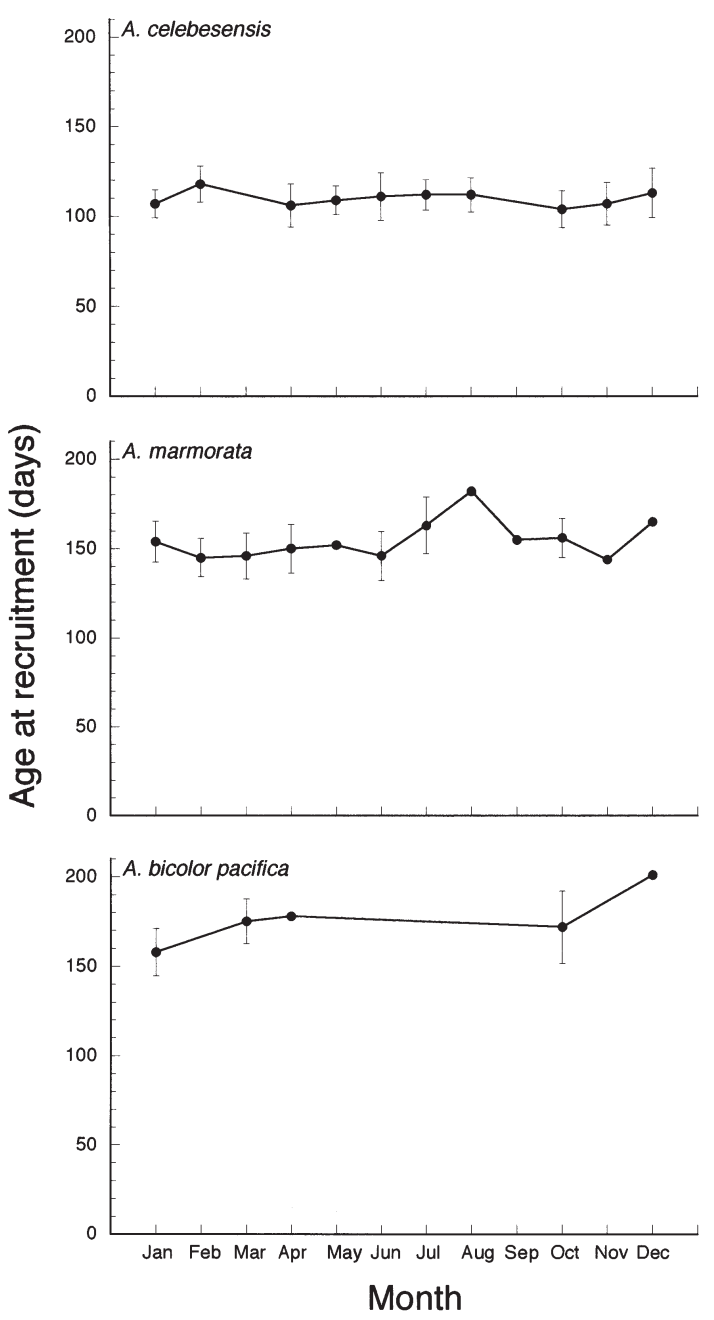

Fig. 7. Anguilla celebesensis, A. marmorata and A. bicolor pacifica. Seasonal variations in age at recruitment of glass eels caught at the mouth of the Poigar River in 1997

month ranged from 104 (October) to 118 d (February), 144 (November) to $182 \mathrm{~d}$ (August) and 158 (January) to 201 d (December), respectively (Fig. 7). No significant difference occurred among months in any one species (ANOVA, p > 0.1). However significant differences occurred in all combinations among species (ANOVA, $\mathrm{p}<0.0001)$. The ages at recruitment of A. celebesensis, A. marmorata and $A$. bicolor pacifica were (mean \pm SD) $109 \pm 10.9,155 \pm 14.8$ and $173 \pm 20.9$ d, respectively.

Close linear relationships were apparent between age at metamorphosis and age at recruitment in all species (Fisher's Z-transformation, p < 0.0001) (Fig. 8), being similar to those observed in temperate eels Anguilla japonica (Tsukamoto \& Umezawa 1994), A. australis (Arai et al. 1999d), A. anguilla and A. rostrata (Arai et al. 2000b) and A. dieffenbachi (Marui et al. 2001). 


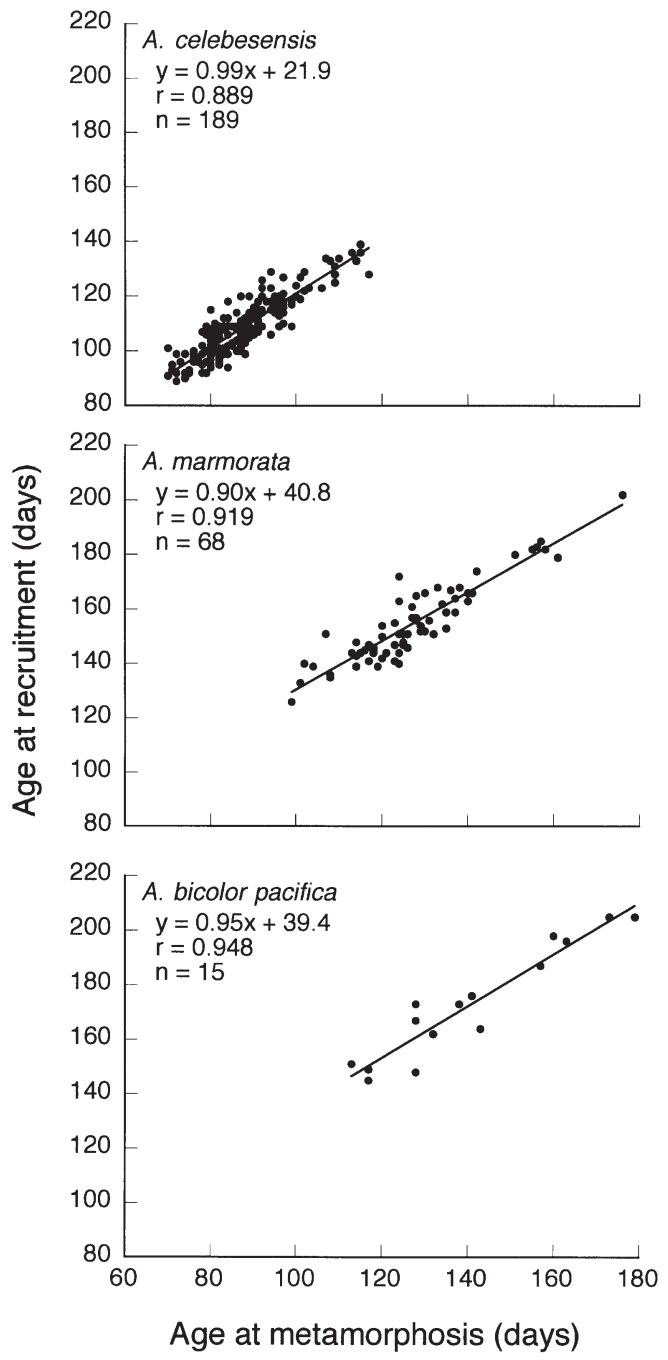

Fig. 8. Anguilla celebesensis, A. marmorata and A. bicolor pacifica. Relationship between age at metamorphosis and age at recruitment in glass eels caught at the mouth of the Poigar River in 1997

\section{Inshore migration period}

The mean inshore migration periods after metamorphosis of Anguilla celebesensis, A. marmorata and A. bicolor pacifica in each month ranged from 4 (October) to $7 \mathrm{~d}$ (December), 4 (November) to $12 \mathrm{~d}$ (February) and 9 (December) to $22 \mathrm{~d}$ (October), respectively (Fig. 9). No significant difference occurred among months in any one species (ANOVA, p > 0.1), whereas significant differences occurred in all combinations among species (ANOVA, p $<0.005$ to 0.0001). The inshore migration periods of $A$. celebesensis, A. marmorata and $A$. bicolor pacifica were (mean \pm SD) $5 \pm$ $3.2,9 \pm 4.3$ and $14 \pm 6.6 \mathrm{~d}$, respectively, the differences suggesting that the metamorphosis area differed among species.

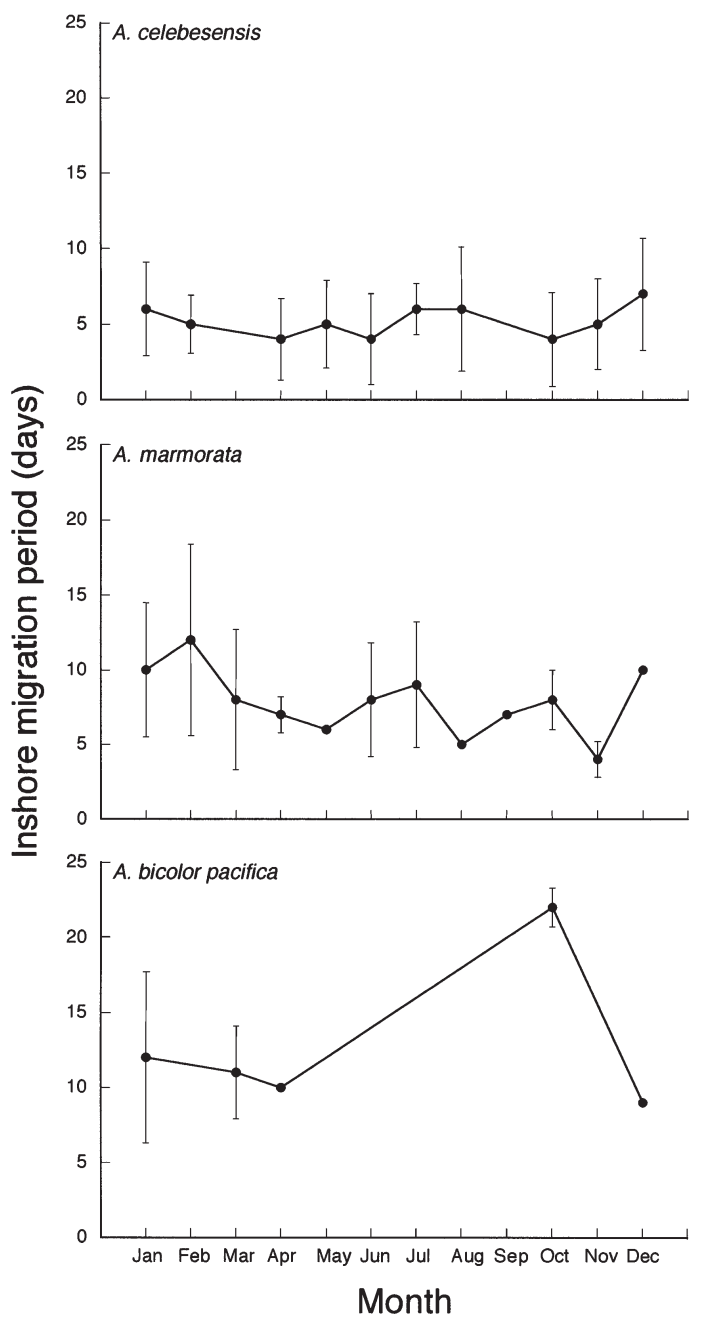

Fig. 9. Anguilla celebesensis, A. marmorata and A. bicolor pacifica. Seasonal variations in inshore migration period of glass eels caught at the mouth of the Poigar River in 1997

\section{Hatch date}

The estimated hatching dates, back-calculated from sampling date and ages, were distributed throughout the year (from July 1996 to June 1997) for Anguilla marmorata (Fig. 10) and similarly for A. celebesensis (from September 1996 to August 1997), except for May and November. However, no hatching dates were found in October 1996 or from December 1996 to March 1997 for A. bicolor pacifica.

\section{DISCUSSION}

\section{Metamorphosis}

Age at metamorphosis and duration of the metamorphosis stage of the tropical eels Anguilla celebesensis, 

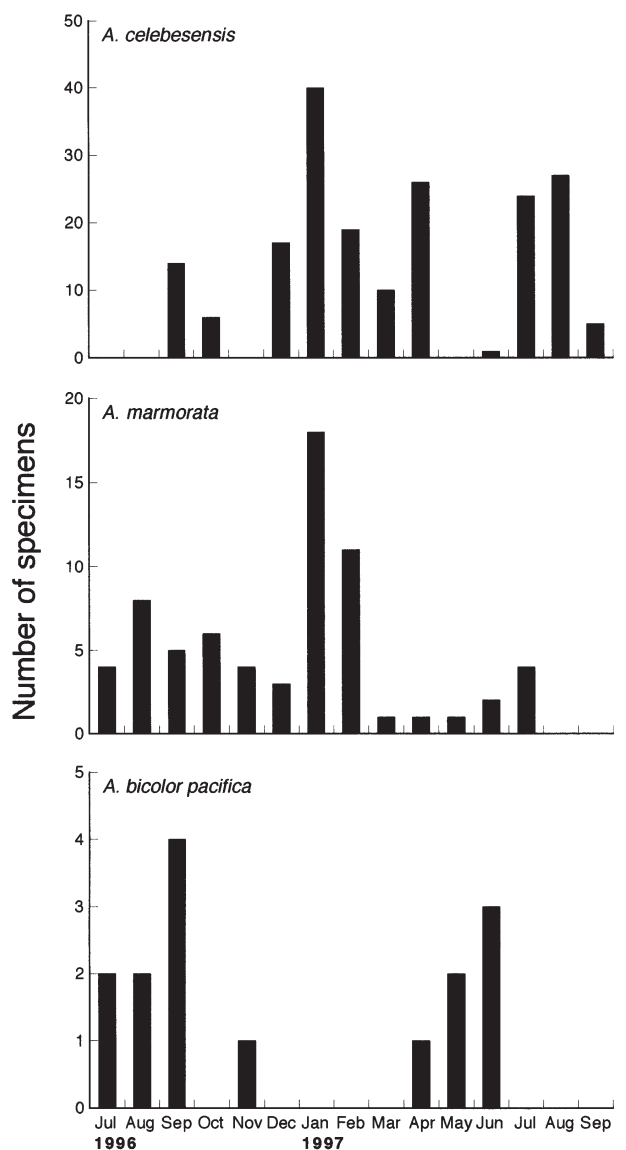

Hatching date (month)

Fig. 10. Anguilla celebesensis, A. marmorata and A. bicolor pacifica. Hatching date determined from otoliths of 272 glass eels caught at the mouth of the Poigar River in January to December 1997

A. marmorata and A. bicolor pacifica, were constant throughout the year regardless of differing recruitment seasons between the species. A. celebesensis, A. marmorata and $A$. bicolor pacifica leptocephali required about 3 to 5 mo to metamorphose after hatching. In temperate eels (for example, A. japonica) it has been revealed that earlier-hatching individuals are recruited to estuarine habitats relatively earlier in the recruitment season (Tsukamoto 1990, Tsukamoto \& Umezawa 1994). In A. japonica, recruitment occurs over a limited period (winter and spring) (Matsui 1972), with its spawning period also being limited (from April to November) (Tsukamoto 1990). Individuals with earlier hatching dates and faster growth rates begin metamorphosis earlier, the age at metamorphosis therefore possibly changing as a result of differences in time of spawning. In comparison, tropical eels, in which spawning persists throughout the year, have a constant age at recruitment throughout the year and most probably have constant larval growth rates throughout the year.
Ages at metamorphosis (duration of leptocephalus stage) of Anguilla celebesensis, A. marmorata and A. bicolor pacifica were 1 to 5 mo less than those of temperate eels, A. anguilla (7 mo) (Lecomte-Finiger 1992, Arai et al. 2000b), A. rostrata (6 to $7 \mathrm{mo}$ ) (Wang \& Tzeng 1998, Arai et al. 2000b), A. australis (6 mo) (Arai et al. 1999d) and A. dieffenbachi (8 mo) (Marui et al. 2001), except for A. japonica (5 mo) (Cheng \& Tzeng 1996, Arai et al. 1997) (Fig. 11). The relationship between the timing of metamorphosis and age at recruitment clearly showed that glass eels metamorphosing earlier tended to migrate to a coastal region at a younger age, indicating that early metamorphosing larvae are recruited relatively sooner (Fig. 8). Tsukamoto \& Umezawa (1994), Arai et al. (1999d, 2000b) and Marui et al. (2001) found the same phenomenon in the temperate eels A. japonica , A. australis, $A$. anguilla and A. rostrata and $A$. dieffenbachi, respectively. These considerations suggest that timing of metamorphosis is a key factor in larval migration of anguillid eels.

The leptocephali of tropical and temperate eels probably experience different environmental temperatures during their migration from spawning areas to estuarine habitats. This would likely lead to differences in the timing of the onset and duration of metamorphosis. Typical vertical temperatures in openocean waters at the surface and 200 m, where Anguilla leptocephali have been collected (Castonguay \&

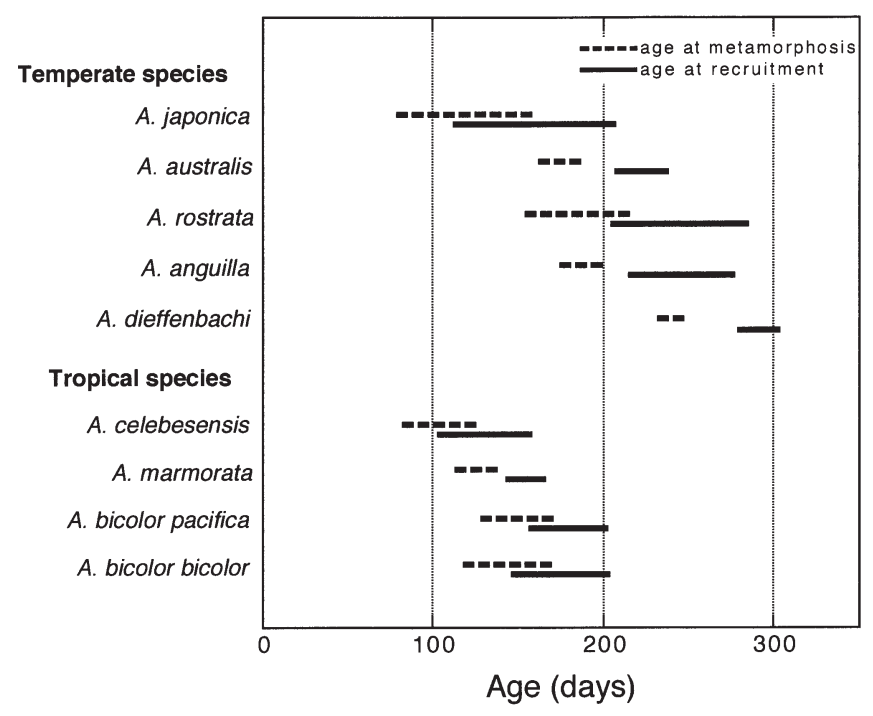

Fig. 11. Anguilla spp. Age at metamorphosis and recruitment of temperate and tropical species, determined by the present study and previous SEM studies, including temperate eels $A$. japonica (Tabeta et al. 1987, Tzeng 1990, Cheng \& Tzeng 1996, Arai et al. 1997), A. anguilla (Lecomte-Finiger 1992, Arai et al. 2000b), A. rostrata (Wang \& Tzeng 1998, Arai 2000b), A. australis (Arai et al. 1999d) and A. dieffenbachi (Marui et al. 2000), and tropical eels A. bicolor pacifica (Arai et al. 1999c) and A. celebesensis, A. marmorata and A. bicolor bicolor (Arai et al. 1999b) 
McCleave 1987, Otake et al. 1998), are 20 to $25^{\circ} \mathrm{C}$ in tropical areas and 10 to $20^{\circ} \mathrm{C}$ in temperate areas (Apel 1987, Pickard \& Emery 1990), the spawning areas of both tropical and temperate eels being in tropical areas (Schmidt 1922, 1925, Tsukamoto 1992). The former experience high tropical temperature environments during migration, whereas the latter experience drastic changes in temperature environments during migration. Lower temperature environments may lead to slower growth in the latter eels, resulting in delayed metamorphosis. Subsequently, such species may be transported for greater distances in temperate areas.

\section{Recruitment}

Ages at recruitment of Anguilla celebesensis, A. marmorata and $A$. bicolor pacifica were constant throughout the year in each species, possibly a result of their constant age at the onset of metamorphosis throughout the year. The differences in age at recruitment among the species ( 4 mo in A. celebesensis, 5 mo in A. marmorata and 6 mo in A. bicolor pacifica) may be due to the differences in age at the beginning of metamorphosis of each species. Furthermore, ages at recruitment of these tropical eels were 1 to 6 mo less than those of temperate eels: A. anguilla $=8 \mathrm{mo}$ (Lecomte-Finiger 1992, Arai et al. 2000b), A. rostrata $=$ 7 to 8 mo (Wang \& Tzeng 1998, Arai et al. 2000b), A. australis $=7$ mo (Arai et al. 1999d), and A. dieffenbachi = 10 mo (Marui et al. 2001), except for A. japonica (6 mo: Cheng \& Tzeng 1996, Arai et al. 1997) (Fig. 11). This may be because the age at metamorphosis in the former species is 1 to 5 mo less than in A. japonica.

Anguilla marmorata from the mouth of Cagayan River, Philippines, metamorphosed at $120 \mathrm{~d}$ and was recruited at $154 \mathrm{~d}$ (Arai et al. 1999b), suggesting that early life-history parameters such as age at both metamorphosis and recruitment were almost the same in $A$. marmorata at the Poigar and Cagayan Rivers, despite their different geographical distribution and probable ocean migration routes (Fig. 12). A molecular study on the population structure of A. marmorata clearly demonstrated that A. marmorata was divided into 6 geographical populations, with specimens from the Cagayan and Poigar Rivers belonging to the North Pacific population (Ishikawa 1998), which is believed to spawn in an area around $15^{\circ} \mathrm{N}, 143^{\circ} \mathrm{E}$ (Fig. 12) (Arai 2000). This area is southeast of the spawning area of $A$. japonica (in the North Equatorial Current west of the Mariana Islands) (Tsukamoto 1992). On the basis of the current systems and geographical distribution of adult eels, A. marmorata leptocephali may drift via the North Equatorial and Kuroshio Currents, thereafter migrating to coastal areas of the Philippines, Taiwan, China

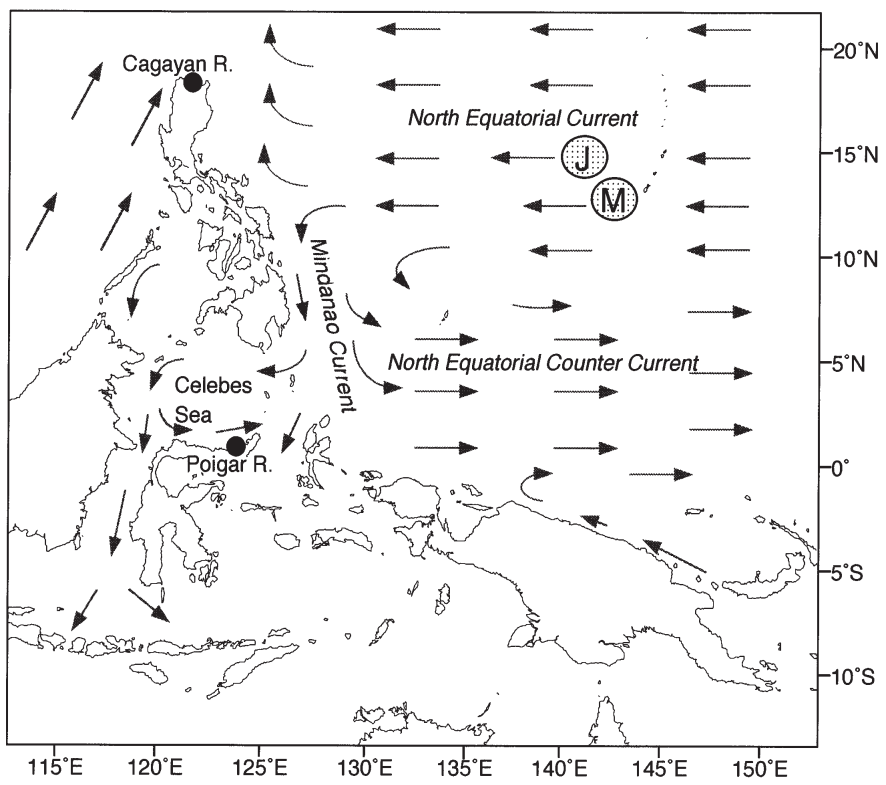

Fig. 12. Map showing prevailing oceanic surface currents, spawning area of Anguilla japonica (J; Tsukamoto 1992) and estimated spawning area of A. marmorata ( $\mathrm{M}_{i}$ Arai 2000) in the western Pacific Ocean and vicinity of the study area (Pickard \& Emery 1990, United States Government 1991, Godfrey et al. 1993, Gordon \& Fine 1996)

and Japan, as does A. japonica. Simultaneously, A. marmorata leptocephali may drift with the Mindanao Current via the North Equatorial Current, thereafter reaching north Sulawesi Island (Fig. 12). A. celebesensis from the Cagayan River, which metamorphoses at $124 \mathrm{~d}$ and is recruited at $157 \mathrm{~d}$ (Arai et al. 1999b), has early life-history parameters 40 to $50 \mathrm{~d}$ longer than those of $A$. celebesensis collected in the Poigar River, but does not differ significantly from the corresponding parameters in A. marmorata collected in the Cagayan River (Arai et al. 1999b). This suggests that the Cagayan River A. celebesensis may have been transported from the vicinity of the spawning area of A. marmorata (North Pacific population). The fact that A. celebesensis in the Poigar River has shorter early life-history parameters (88 $\mathrm{d}$ in age at metamorphosis, $109 \mathrm{~d}$ in age at recruitment) than those of any other eels studied suggests that the distance between its spawning area and the Poigar River may be much shorter than that from the A. marmorata spawning area. Because there are no oceanic current systems directly associated with the coastal areas between the Poigar and Cagayan River mouths (Fig. 12), there may exist at least 2 reproductively isolated populations of A. celebesensis in the Pacific region. Nevertheless, a migration mechanism for eel larvae cannot be interpreted simply as transportation by a steady current system. In order to discriminate between populations 
of A. celebesensis, a molecular analysis of the species should be undertaken.

\section{Hatching}

The spawning seasons of Anguilla celebesensis and A. marmorata extended throughout the year. Although that of $A$. bicolor pacifica was estimated to be about 6 mo based on occurrence in the monthly samples during this study, glass eels of this species have been found throughout the year at the mouth of the Poigar River (Arai 2000), with early life-history parameters such as duration of the leptocephalus stage and age at recruitment being constant throughout the year. Accordingly, the spawning season of $A$. bicolor pacifica may occur throughout the year. In temperate species, spawning occurs over a limited period, i.e. February to April in A. rostrata (McCleave et al. 1987), March to June in A. anguilla (McCleave \& Kleckner 1987), April to November in A. japonica (Tsukamoto 1990), August to December in A. dieffenbachi (Jellyman 1987) and September to February in A. australis (Jellyman 1987). The difference in spawning season duration and timing between tropical and temperate species could be due to differences in the seaward migration seasons of maturing adult eels. Temperate species are known to start spawning migrations within a limited period: August to November in A. rostrata (Hain 1975), August to December in A. anguilla (Haraldstad et al. 1985), August to December in A. japonica (Matsui 1952), April to May in A. dieffenbachi (Jellyman 1987) and February to April in A. australis (Jellyman 1987). In tropical species which spawn yearround, spawning migration may occur throughout the year, although nothing is known yet of seaward migration seasons on tropical maturing adult eels. Yearround spawning of tropical species and constant larval growth throughout the year may extend the period of recruitment to estuarine habitats to year-round in these species, as found in previous studies (Tabeta et al. 1976b, Arai et al. 1999a, Arai 2000).

\section{Oceanic migration}

Anguilla celebesensis, A. marmorata and A. bicolor pacifica leptocephali required about 4 to $6 \mathrm{mo}$ to migrate from their spawning areas to estuarine habitats; A. bicolor bicolor requires a similar period (Arai et al. 1999b). In temperate eels, the duration of oceanic migration seems to be related to the distance and complexity of the current systems between the spawning areas and the eel's freshwater destinations. According to Jespersen (1942), the spawning areas of A. bicolor bicolor and A. celebesensis off Java and the North Sulawesi Islands, respectively, are possibly situated off the south-western coast of Sumatra for the former and the Celebes Sea for the latter species, both of these areas being close to their distribution areas (Figs. 1 \& 12). Therefore, the rather long migration periods of these species relative to the short distances between their growth habitat and spawning area may be due to the complexity of local current systems around Sumatra, Java, and the North Sulawesi Islands. The presence of leptocephali of various sizes and stages, including preleptocephalus to metamorphosing stages, in waters off Sumatra (Jespersen 1942) support this supposition. This situation is quite different from that of temperate eels, suggesting that the migration mechanisms of tropical eel larvae are not as simple as those of temperate eels.

The spawning areas of the genus Anguilla are all located in tropical regions (Schmidt 1922, 1925, Tsukamoto 1992), indicating that freshwater eels may have originated in the tropics (Tsukamoto 1994, Tsukamoto \& Aoyama 1998). The leptocephalus stage is of long duration (3 to $8 \mathrm{mo}$ ) (Fig. 11), and appears to be highly adapted to a marine planktonic life. As the result of their slow growth and passive transport by oceanic currents and wind, it is likely that global dispersal of freshwater eels might have originated from the Indonesian region. Accidental drift of larvae in global circum-equatorial currents and variations in early development may have resulted in variations in the larval stage, that is, expansion of their growth habitat. For temperate eels, retention of their spawning areas in the tropics would necessitate migrations of thousands of kilometers.

In conclusion, ancestral eels most probably underwent diadromous migration from local short-distance movements in complex currents in tropical coastal waters to the long-distant migrations characteristic of present-day temperate eels, which has been wellestablished as occurring in subtropical gyres in both hemispheres.

Acknowledgements. We are grateful to Dr G. S. Hardy, Thames, New Zealand, for his critical reading of the manuscript, and also thank the students of Living Aquatic Resources Management Laboratory, Sam Ratulangi University, for their assistance during the field study. This work was supported in part by Grants-in-Aid Nos. 07306022, 07556046 , 08041139 and 08456094 from the Ministry of Education, Science, Sports and Culture, Japan; Research for the Future Program No. JSPS-RFTF 97L00901 from the Japan Society for the Promotion of Science; Eel Research Foundation from Noborikai; and Research Foundation from Touwa Shokuhin Shinkoukai. Partial support was also given in the form of a Research Fellowship of the Japan Society for the Promotion of Science for Young Scientists to T.A. 


\section{LITERATURE CITED}

Aoyama J (1998) Molecular phylogeny and evolution of the freshwater eels, genus Anguilla. PhD thesis, University of Tokyo

Apel JR (1987) Principles of ocean physics. Academic Press, New York

Arai T (2000) Ecological study on the inshore migration of the eels, Anguilla spp. in Sulawesi Island. PhD thesis, University of Tokyo

Arai T, Otake T, Tsukamoto K (1997) Drastic changes in otolith microstructure and microchemistry accompanying the onset of metamorphosis in the Japanese eel Anguilla japonica. Mar Ecol Prog Ser 161:17-22

Arai T, Aoyama J, Daniel L, Tsukamoto K (1999a) Species composition and inshore migration of the tropical eels, Anguilla spp., recruiting to the estuary of the Poigar River, Sulawesi Island. Mar Ecol Prog Ser 188:299-303

Arai T, Daniel L, Otake T, Tsukamoto K (1999b) Metamorphosis and inshore migration of tropical eels, Anguilla spp., in the Indo-Pacific. Mar Ecol Prog Ser 182:283-293

Arai T, Otake T, Daniel L, Tsukamoto K (1999c) Early life history and recruitment of the tropical eel, Anguilla bicolor pacifica, as revealed by otolith microstructure and microchemistry. Mar Biol 133:319-326

Arai T, Otake T, Jellyman DJ, Tsukamoto K (1999d) Differences in the early life history of the Australasian shortfinned eel, Anguilla australis, from Australia and New Zealand, as revealed by otolith microstructure and microchemistry. Mar Biol 135:381-389

Arai T, Daniel L, Tsukamoto K (2000a) Validation of otolith daily increments in the tropical eel, Anguilla celebesensis. Can J Zool 78:1078-1084

Arai T, Otake T, Tsukamoto K (2000b) Timing of metamorphosis and larval segregation of the Atlantic eels Anguilla rostrata and $A$. anguilla, as revealed by otolith microstructure and microchemistry. Mar Biol 137:39-45

Bertin L (1956) Eels — a biological study. Cleaver-Hume Press Ltd, London

Castle PHJ, Williamson GR (1974) On the validity of the freshwater eel species Anguilla ancestralis Ege from Celebes. Copeia 2:569-570

Castonguay M (1987) Growth of American and European eel leptocephali as revealed by otolith microstructure. Can J Zool 65:875-878

Castonguay M, McCleave JD (1987) Vertical distributions, diel and ontogenetic vertical migrations, and net avoidance of leptocephali of Anguilla spp. and other common species in the Sargasso Sea. J Plankton Res 9:195-214

Cheng PW, Tzeng WN (1996) Timing of metamorphosis and estuarine arrival across the dispersal range of the Japanese eel Anguilla japonica. Mar Ecol Prog Ser 131:87-96

Ege V (1939) A revision of the Genus Anguilla Shaw. Dana Rep 16(13):8-256

Godfrey JS, Hirst AC, Wilkin J (1993) Why does the Indonesian throughflow appear to originate from the North Pacific? J Phys Oceanogr 23:1087-1098

Gordon AL, Fine RA (1996) Pathways of water between the Pacific and Indian Oceans in the Indonesia Seas. Nature 379:146-149

Hain JHW (1975) The behavior of migratory eels, Anguilla rostrata, in response to current, salinity and lunar period. Helgol Meeresunters 27:211-233

Haraldstad O, Vollestad LA, Jonsson B (1985) Descent of European silver eels, Anguilla anguilla L., in a Norwegian watercourse. J Fish Biol 26:37-41

Ishikawa S (1998) Molecular study on the population struc- ture of Anguilla marmorata. PhD thesis, University of Tokyo

Jellyman DJ (1987) Review of the marine life history of Australasian temperate species of Anguilla. Am Fish Soc Symp 1:276-285

Jespersen P (1942) Indo-Pacific leptocephali of the genus Anguilla. Dana Rep 22:1-128

Lecomte-Finiger R (1992) Growth history and age at recruitment of European glass eels (Anguilla anguilla) as revealed by otolith microstructure. Mar Biol 114: 205-210

Martin MH (1995) Validation of daily growth increments in otoliths of Anguilla rostrata (Lesueur) elvers. Can J Zool 73:208-211

Marui M, Arai T, Miller MJ, Jellyman DJ, Tsukamoto K (2001) Comparison of early life history between New Zealand temperate eels and Pacific tropical eels revealed by otolith microstructure and microchemistry. Mar Ecol Prog Ser 213:273-284

Matsui I (1952) Morphology, ecology and culture of the Japanese eel. J Shimonoseki Coll Fish 2:1-245

Matsui I (1972) Eel biology-biological study. KoseishaKoseikaku, Tokyo

McCleave JD, Kleckner RC, Castonguay M (1987) Reproductive sympatry of American and European eels and implications for migration and taxonomy. Am Fish Soc Symp 1: 286-297

Otake T, Ishii T, Nakahara M, Nakamura R (1994) Drastic changes in otolith strontium/calcium ratios in leptocephali and glass eels of Japanese eel Anguilla japonica. Mar Ecol Prog Ser 112:189-193

Otake T, Inagaki T, Hasumoto $\mathrm{H}$, Mochioka N, Tsukamoto K (1998) Diel vertical distribution of Anguilla japonica leptocephali. Ichthyol Res 45:208-211

Pickard GL, Emery WJ (1990) Descriptive physical oceanography. Pergamon Press, Oxford

Schmidt J (1922) The breeding places of the eel. Philos Trans R Soc Lond B Biol Sci 211:178-208

Schmidt J (1925) The breeding places of the eel. Annu Rep Smithson Inst 1924:279-316

Sokal RR, Rohlf FJ (1969) Biometry. The principles and practice of statistics in biological research. WH Freeman \& Co, San Francisco

Tabeta O, Takai T, Matsui I (1976a) The sectional counts of vertebrae in the anguillid elvers. Jpn J Ichthyol 22: 195-200

Tabeta O, Tanimoto T, Takai T, Matsui I, Imamura T (1976b) Seasonal occurrence of anguillid elvers in Cagayan River, Luzon Island, the Philippines. Bull Jpn Soc Sci Fish 42: 421-426

Tabeta O, Tanaka K, Yamada J, Tzeng WN (1987) Aspects of the early life history of the Japanese eel Anguilla japonica determined from otolith microstructure. Bull Jpn Soc Sci Fish 53:1727-1734

Tsukamoto K (1989) Otolith daily growth increments in the Japanese eel. Bull Jpn Soc Sci Fish 55:1017-1021

Tsukamoto K (1990) Recruitment mechanism of the eel, Anguilla japonica, to the Japanese coast. J Fish Biol 36: 659-671

Tsukamoto K (1992) Discovery of the spawning area for the Japanese eel. Nature (Lond) 356:789-791

Tsukamoto K (1994) Freshwater fishes migrating between river and the sea. Tokai University Press, Tokyo

Tsukamoto K, Aoyama J (1998) Evolution of freshwater eels of the genus Anguilla: a probable scenario. Environ Biol Fish 52:139-148

Tsukamoto K, Umezawa A (1990) Early life history and ocea- 
nic migration of the eel, Anguilla japonica. La Mer 28: 188-198

Tsukamoto K, Umezawa A (1994) Metamorphosis: a key factor of larval migration determining geographic distribution and speciation of eels. Proceedings of the Fourth Indo-Pacific Fish Conference, Bangkok, Thailand. Faculty of Fisheries Kasetart University 1994, p 231-248

Tzeng WN (1990) Relationship between growth rate and age at recruitment of Anguilla japonica elvers in a Taiwan estuary as inferred from otolith growth increments. Mar Biol 107:75-81

Tzeng WN, Tsai YC (1992) Otolith microstructure and daily age of the Anguilla japonica, Temminck and Schlegel elvers from the estuaries of Taiwan with reference to unit stock and larval migration. J Fish Biol 40:845-857

Umezawa A, Tsukamoto K (1990) Age and birth date of the glass eel, Anguilla japonica, collected in Taiwan. Bull Jpn Soc Sci Fish 56:1199-1202

Editorial responsibility: Otto Kinne (Editor), Oldendorf/Luhe, Germany
Umezawa A, Tsukamoto K (1991) Factors influencing otolith increment formation in Japanese eel, Anguilla japonica T. and S., elvers. J Fish Biol 39:211-223

Umezawa A, Tsukamoto K, Tabeta O, Yamakawa H (1989) Daily growth increments in the larval otolith of the Japanese eel, Anguilla japonica. Jpn J Ichthyol 35: 440-444

United States Government (1991) Atlas of pilot charts, Indian Ocean. Defense Mapping Agency, Washington, DC

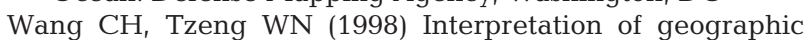
variation in size of American eel Anguilla rostrata elvers on the Atlantic coast of North America using their life history and otolith ageing. Mar Ecol Prog Ser 168: $35-43$

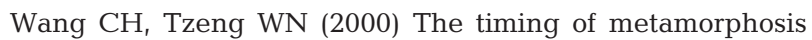
and growth rates of American and European eel leptocephali: a mechanism of larval segregative migration. Fish Res 46:191-205

Submitted: September 13, 2000; Accepted: December 8, 2000 Proofs received from author(s): June 8, 2001 